\title{
Natural Resources and the Economic Growth of West Africa Economies
}

\author{
Michael Asiedu ${ }^{1}$, Ebenezer Nana Yeboah ${ }^{2}, \&$ David Owusu Boakye ${ }^{3}$ \\ ${ }^{1}$ School of Finance, Zhongnan University of Economics and Law, Wuhan - China \\ ${ }^{2}$ School of Accounting, Zhongnan University of Economics and Law, Wuhan - China \\ ${ }^{3}$ School of Business Administration, Wuhan University of Science and Technology, Wuhan - China \\ Correspondence: Michael Asiedu, School of Finance, Zhongnan University of Economics and Law, Wuhan - China.
}

Received: November 12, 2020

Accepted: January 29, $2021 \quad$ Available online: February 8, 2021

doi:10.11114/aef.v8i2.5157

URL: https://doi.org/10.11114/aef.v8i2.5157

\begin{abstract}
In this study, we employed the pooled mean group (PMG) regression to examine the effect of natural resources economic rent (coal rent, gas rent, oil rent, forest rent, minerals rent) and foreign direct investment (FDI) on economic growth in West Africa for the period 1996 to 2017. We found strong evidence of a positive relationship between FDI, total natural resources (TNR), total natural gas (TNG), and economic growth in the long-run. However, the study recorded a negative relationship between mineral resources rent, oil rent and gas rent, and economic growth in the long run. The rent from coal also exhibited neutrality on economic growth. While all the short-run coefficients are not statistically significant, the error correction term (ECT) is significant and a negative value of -0.889 , signifying cointegration at a $1 \%$ significance level. This also implies that the short-run estimates converge towards the long-run estimates to achieve equilibrium at the speed of $89 \%$ per annum. Our findings highlight the significance of FDI and total rent from natural resources in stimulating West African economies' growth in the industrialization drive and general welfare. In contrast, this study also highlights the need for policy direction to redesign and realign ownership in the oil and gas sector from multinational co-operations (MNCs) to the locals and the domestic economy to benefit directly from the prevailing environment.
\end{abstract}

Keywords: natural resources, economic growth, oil rent, gas rent, forest rent, coal rent, FDI, West Africa

\section{Introduction}

Several questions have been raised in the development economics literature about the significance of natural resources and how natural resource-rich countries are affected in their long-term growth. Ordinarily, countries with more natural resources would be assumed to have increased wealth and more purchasing power (Holden (2013). However, countries in West Africa endowed with many natural resources seem to struggle with reducing poverty. The achievement of laid down poverty reduction projections is a hurdle far from reaching because of insignificant growth rates. With nearly $40 \%$ of empirical studies suggesting negative evidence, $20 \%$ recording positive effect and a significant $40 \%$ finding no effect on the economy, leaves no consensus on this subject. Gerelmaa \& Kotani (2013) applied quantile regression to examine the popular economic literature on the natural resource curse and the Dutch disease. The literature mostly amplifies why countries with rich natural resources often experience lower and slower economic growth than countries with less natural resources. First, they established that resource-rich countries in 1970 experienced slower economic growth than countries with less natural resources for the following 20 years. Secondly, contrary to their initial expectations, they found that the abundance of natural resources in 1990 had a significant and positive effect on economic growth between 1990 and 2010. The test results from the Dutch disease theory found contradicting results. Between 1970 and 1990, Gerelmaa \& Kotani (2013), however, upheld the Dutch disease theory based on their findings. However, from 1990 to 2010, the Dutch disease hypothesis disappeared due to the significant growth in the manufacturing sectors of even highly resource endowed countries. From a quantitative survey of 605 estimates recorded in 43 studies, Havranek et al. (2016) found that considering potential publication bias and methodology heterogeneity into account; the natural resource curse hypothesis is weak. Their study found further proof of four elements of study designs that are very effective in accounting for the differences in result across studies (i) accounting for institutional quality, (ii) accounting for investment activities, (iii) defining the various types of natural resources (iv)defining resource dependence from abundance. 
Huang (2020) employed the Pool Mean Group (PMG) regression to examine the effects of natural resource utilization and foreign direct investment on economic growth using data of 25 developing countries in Asia for the period 1996 to 2016. The study found that FDI stimulates economic growth in Asia. However, the effect of total natural resources was found to be insignificant on economic growth. In contrast, the study found evidence of a significant relationship between economic growth and the rent received from forest resources, mineral resources, and oil. Robust financial systems are critical in the transmission of natural resource revenues into productive investment. Erdoğan et al. (2020) investigated the linkage between natural resource export, economic growth, and the level of financial deepening using data of Next-11 countries for the period spanning 1996 to 2016 by employing nonlinear panel data technique in two regimes. Evidence was found that, when the rate of financial deepening was below $45 \%$, an increase in oil export did not significantly affect economic growth in the first regime. Economic growth increased by $7 \%$ in the second regime when financial deepening is more than $45 \%$. Redmond \& Nasir (2020) employed a balanced panel of 30 countries from 1990 to 2016 to investigate the impact of natural resource abundance, trade openness, international trade, financial development, and institutional quality on economic growth and a human development index. The empirical model results found a positive and significant effect of natural resource abundance on economic growth but a negative effect on human development.

In contrast, international trade and broad money reported adverse effects on economic development. Hence, Pérez \& Claveria (2020) introduced a novel approach as a visual interrogation of the relationship between human development, economic growth, and a set of factors that represents the dependence of mineral resources in ten (10) African countries considered the highest exporters of mineral resources for the period 2007 to 2016 . The empirical evidence found a tenuous negative relationship between average growth in human development and the corresponding weighted mineral rent. Based on their empirical results, they concluded that from among other results, since the average growth in resource rent does not translate into higher economic growth, it is a clear indication that corruption may be the main stumbling block to economic development. Their findings also highlight the need to advance institutional quality and design proper mining models to alleviate the challenges bedeviled among mineral dependent African countries. Hao et al. (2019) built upon the environmental Kuznets curve (EKC) to examine the relationship between water resource use and economic growth in panel data analysis of 29 provinces in China from 1999 to 2014. Evidence was found that the relationship between per capita water consumption and per capita GDP was "N" shaped. They also found the contribution of industrial water use to economic development as positive. Simultaneously, a nonlinear relationship was recorded between GDP per capita and total and non-industrial water consumption.

Soejoto, Ady, et al. (2017) analyzed the factors underling Southeast Asia countries' economic growth using panel regression technique to ascertain the impact of investment, labor, natural resources, and technology toward economic growth (Solow variable). Evidence was found that the Solow variable significantly affected each country differently. For instance, economic growth was significantly affected by investment, human resources, and labor in Indonesia and Brunei. In Thailand and the Philippines, economic growth is significantly affected by investment, natural resources, and labor. Olayungbo (2019) also adopted the Bayesian time-varying parameter (TVP) model to examine how Nigeria's economic growth is affected by oil revenue in an attempt to verify the natural resource curse hypothesis. Using annual time series data from 1970 to 2015, the study established a positive and significant effect of exported oil revenue on economic growth for the period under investigation. In contrast, the study also found that unfavorable trade openness and low quality of education accounts for the slow economic growth in Nigeria regardless of the enormous oil rent received over the same period.

This paper sets to find inherent assertions regarding the effect of the Natural resource curse on economic rent in West Africa. It augments agencies such as USAID's efforts working through various regional organizations and private sector associations to address dire limitations to competitiveness and unveil West Africa's productive perspective to activate more significant economic growth. The rest of this research paper is structured as follows. Section 2 briefly discusses prior empirical studies on the resource curse and economic growth. In Section 3, the dataset used and its source, empirical model, the methodology is outlined. In Section 4, the results are presented, finally, in Section 5, the main conclusions of this study and discussions for future extensions in this research line.

\section{Literature Review}

Africa economies are currently one of the many economies that report enormous natural resources discoveries (oil, minerals, coal, gas). If the right systems and conditions are instituted, natural resource rents may be a catalyst for economic growth and further transit these developing economies into improved living standards. However, managing abundant resources, especially in Africa, have produced mixed results. The results are mixed with optimism and anxiety for the growth of the economy.

Zallé (2019) examined the conditional impact of the dependence on natural resources on human capital development and institutional quality on economic growth by employing an Autoregressive Distributed Lag estimation technique on 
a sample of 29 countries where the average level of dependency was $19.53 \%$ between the year 2000 and 2015 . The study found that the interactions between both (i) natural resources and institutional quality, (ii) the interactions between natural resources and human capital proves that the coupe human capital-corruption is an ideal lever to exploit natural resources in Africa. Therefore, the study concluded that African countries need to strengthen and accelerate their human capital investments and rigorously heighten the fight against corruption. Havranek et al. (2018) presented the first evidence on the effects of publication selection in the literature by estimating water demand's income elasticity. They found the mean underlying elasticity as approximately 0.15 or less after controlling for more than 30 features of the estimates and accommodating model uncertainty. The estimates were systematically found due to variations in tariff structure, regional coverage, data granularity, and temperature control. Under the resource curse hypothesis, Abdulahi et al. ( 2019) adopted institutional quality (IQ) as a threshold variable and examined the nonlinear relationship between natural resource rent and economic growth. From a panel sample of 14 natural resource-rich countries of Sub-Saharan Africa, the study confirmed a positive relationship between resource rent and economic growth when a country's institutional quality (IQ) is above the threshold level of -1.28 and within the range of -1.28 to -1.37 . However, when the country's institutional quality (IQ) is less than the threshold level of -1.37 , the resource curse starts to manifest, hindering economic growth. Ben-Salha et al. (2018) contributed to the existing literature on the relationship between natural resource rents and economic growth by also focusing on the causal relationship between total natural resource rents and economic growth in a sample of top resource-abundant countries over the period 1970-2013 by the Pooled Mean Group (PMG) estimation technique. While they found a long positive effect of natural resource rent on economic growth, no evidence was found in the short run. The study also found that economic growth had a positive effect on natural resource rent. Amiri et al. (2019) investigated the effects of natural resource rents and the quality of institutions on the performance of tradable and non-tradable sectors in resource-rich countries from the year 2000 to 2016 by a panel analysis of 28 countries. The panel estimations found evidence that improvement in institutional efficiency in natural resource-based countries, by eradicating or removing the consequences of the natural resource curse phenomenon, improves the performance of the manufacturing sectors of these economies. Further estimates also found the ratio of value added to manufacturing value added increases in natural resource dependent countries unless the level of institutional quality is high.

Horváth \& Zeynalov (2016) also examined how natural resources' export impacted 15 independent countries' economies formerly in the Soviet Union from 1996-2010. The study employed several panel estimation methods to overcome the endogeneity and clustering issues among these countries. After the collapse of the Soviet Union, these countries exhibited remarkable heterogeneity resulting in unique cross-sectional variations. The study established a crowding-out effect of natural resources on manufacturing except where domestic institutions are significant of high quality. Hassan et al. (2019) examined the causal relationship between globalization and natural resources on Pakistan's economic growth from 1970 to 2014. They employed the autoregressive distributive lag estimation technique. They established a positive effect of globalization and natural resources on economic growth in Pakistan. They also established bi-directional causality between natural resources and globalization

Henri (2019) employed the two-stage least squares (2SLS) method to examine the linkages in institutional and economic indicators that negatively affect natural resource rents in Africa from 1992 to 2016. Evidence was found that the most institutional problems associated with natural resource rents are corruption, the rule of law or justice, weak public administrations, weak and poor regulation, lack of accountability, and political instability. Rents from natural resources also caused volatility in GDP per capita, resulting in a low quality of physical and human capital accumulation. Madreimov \& Li (2019) found evidence of an inverted U-shaped relationship between natural-resource dependence and longevity by re-examining the relationship between natural resources and the quality of life measured by the life expectancy from the year 1990 to 2011. By implication, the dependence on natural resources negatively affects human development. Henry (2019) examined the natural resource curse phenomenon in sub-Saharan Africa characterized by high dependence on natural resources, weak institutions, and weak growth by introducing time perspective; long term and short term. The results of the study were presented in three folds; (i) negative impact of natural resources dependence was recorded in all categories in the long run (ii) countries with weak institutions are more susceptible to the resource curse because their path to recovery is also adversely affected the resource dependence (iii) results directs to a potential positive impact of natural resources during the recovery process in a robust institutional environment. Wegenast et al. (2018) extended their micro-level arguments by employing data on local economic activity and a set of new data that establishes rights over hydrocarbons resource extraction sites. Based on this unique data set covering the period 1997 to 2014, they performed district and grid-level analysis of sub-Saharan Africa. The analysis presented evidence of increased growth in local and national oil companies, whereas no effect from international oil companies' operations was recorded. Mueller (2019) tested and examined the hypothesis that increasing levels of both forms of Natural resource development, extractive and non-extractive, are associated with diminishing returns to economic prosperity in rural America from 2000 to 2015. The study found that extractive 
development displays the expected outcome in all the remote counties. In contrast, the non-extractive development exhibited a generally adverse effect on per capita income, a positive effect on poverty, and no effect with inequality.

Rantao (2019) examined multinational co-operations (MNCs) operations in Mozambique's gas fields to investigate the resource curse's causal channels in Mozambique. He employed both an exploratory case study and secondary data, and he identified that MNCs (i) promote and prioritize their CSR activities to hide their failure to uphold local content laws and (ii) take advantage of the diplomatic relationships of their parent country government to dominate the sovereignty of the host country. Tuna \& Tuna (2019) employed the Hacker \& Hatemi-J (2006) tests for symmetric causality and (Abdulnasser Hatemi-J (last), 2012) test to examine asymmetric causality between energy consumption and economic growth for ASEAN-5 countries between 1980 and 2015. The study provided different interactions based on the realization of positive and negative shocks. Such finding provides support to the argument that ASEAN-5 countries should re-orient to orientate to renewable energy policies.

\section{Data Source Empirical model and methodology}

The data set for this study consist of a panelist of 15 countries constituting the Economic Community of West Africa sourced from the World Development Indicators database. The countries under consideration are Ghana, Togo, Niger, Nigeria, Mali, Burkina Faso, Senegal, Sierra Leone, Benin, Ivory Coast, Cape Verde, Mauritania, Gambia, Guinea, and Guinea Bissau. The only country left out is Liberia due to missing values. The panel data of selected variables span from 1996 to 2017. Economic growth is the dependent variable and is measured as GDP growth (annual \%). The independent variables are FDI, taken as net inflows (\% of GDP), total natural resources rents (\% of GDP), Mineral rents ( $\%$ of GDP), Forest rents ( $\%$ of GDP), Coal rent (\% of GDP), total natural gas rent (\% of GDP) and Oil rents (\% of GDP).

Our model's functional specification is inspired by (Huang 2020) based on their study of economic growth in Asia as a function of natural resources (forest rents, fossil fuel energy consumption, FDI, mineral rents, total natural resource rents, and oil rents). Theoretically, natural resources are expected to positively impact economic growth through the rents received in forest rents, mineral rents, gas rent, oil rents, coal rent, and total natural rents. The econometric model of natural resource utilization, net foreign direct investment (FDI), and economic growth is specified below as;

$$
G D P=f(F D I, F R, \quad M R, \quad T N R, T N G, O R, C R)
$$

Where;

$G D P$ is gross domestic product growth (annual \%)

$F D I$ is foreign direct investment, net inflows (\% of GDP),

$F R$ is forest rents (\% of GDP)

$M R$ is mineral rents (\% of GDP)

$T N R$ is natural resources rents (\% of GDP)

$T N G$ is total natural gas rent (\% of GDP)

$O R$ is Oil rents (\% of GDP)

$C R$ is Coal rent (\% of GDP)

Equation (1) is linearly expressed for the empirical analysis and follows (Huang, 2020) as:

$$
G D P_{i t}=\alpha_{0}+\alpha_{1} F D I_{i t}+\alpha_{2} F R_{i t}+\alpha_{3} M R_{i t}+\alpha_{4} T N R_{i t}+\alpha_{5} T N G_{i t}+\alpha_{6} O R_{i t}+\alpha_{7} C R_{i t}+
$$

In the above linear equation, $t$ denotes time, $i$ denote countries,

The parameters $\alpha_{1}$ to $\alpha_{7}$ are the slopes of the explanatory variables, and $\alpha_{0}$ is the intercept. Based on macroeconomic theory, all the parameters $\left(\alpha_{1}\right.$ to $\left.\alpha_{7}\right)$ are positively related to economic growth. 
Tabel 1. Descriptive Statistics

\begin{tabular}{lrrrrr}
\hline Variable & Obs & Mean & Std.Dev. & Min & Max \\
\hline GDP & 330 & 4.456 & 4.498 & -28.1 & 26.417 \\
FDI & 330 & 3.257 & 3.993 & -1.032 & 32.301 \\
TNR & 330 & 11.082 & 8.942 & 0 & 54.379 \\
TNG & 330 & .29 & .836 & 0 & 5.06 \\
MR & 330 & 3.68 & 7.537 & 0 & 46.625 \\
FR & 330 & 6.289 & 4.725 & 0 & 31.591 \\
OR & 330 & 1.235 & 3.461 & 0 & 20.923 \\
CR & 330 & .005 & .021 & 0 & .152 \\
\hline
\end{tabular}

The table above reports the variables' descriptive statistics and gives insight into the model's overall fitness and credibility. This statistic comprises the mean, standard deviation, minimum, and maximum values of all interest variables.

GDP growth (GDP), FDI as a net foreign direct investment (\%GDP), TNR total natural resources (\%GDP), TNG as total natural gas (\%GDP), MR as mineral resources rent (\%GDP), FR as forest rent (\%GDP), OR as oil rent (\%GDP) and $\mathrm{CR}$ as coal rent (\%GDP)

Table 2. Pairwise correlations

\begin{tabular}{lllllllll}
\hline Variables & $(1)$ & $(2)$ & $(3)$ & $(4)$ & $(5)$ & $(6)$ & $(7)$ & $(8)$ \\
\hline (1) GDP & 1.000 & & & & & & & \\
(2) FDI & $0.161^{*}$ & 1.000 & & & & & \\
(3) TNR & 0.019 & $0.225^{*}$ & 1.000 & & & & \\
(4) TNG & 0.015 & $-0.126^{*}$ & $-0.306^{*}$ & 1.000 & & & \\
(5) MR & 0.066 & $0.352^{*}$ & $0.801^{*}$ & $-0.133^{*}$ & 1.000 & & & \\
(6) FR & $-0.149^{*}$ & $-0.118^{*}$ & $0.336^{*}$ & $-0.294^{*}$ & $-0.118^{*}$ & 1.000 & & \\
(7) OR & 0.107 & -0.036 & $0.306^{*}$ & 0.106 & 0.041 & $-0.269^{*}$ & 1.000 & \\
(8) CR & 0.002 & 0.032 & 0.001 & -0.082 & -0.102 & $0.179^{*}$ & -0.035 & 1.000 \\
\hline
\end{tabular}

* shows significance at the .05 level

We identify the pairwise correlation among the variables and the problem of multicollinearity. The correlation matrix identifies the strength of the bond between two variables. A high dependency or bond measured by the correlation coefficient signifies the presence of multicollinearity. However, we report the severity of the multicollinearity by the vector inflation factor (VIF).

Table 3. Im-Pesaran-Shin unit-root test

\begin{tabular}{|c|c|c|c|c|}
\hline \multirow[t]{2}{*}{ Variable } & \multicolumn{2}{|l|}{ Level } & \multicolumn{2}{|c|}{$1^{\text {st }}$ difference } \\
\hline & Statistic & $\mathrm{P}$-value & Statistic & P-value \\
\hline GDP growth & -6.2696 & $0.0000 * * *$ & -14.3610 & $0.0000 * * *$ \\
\hline FDINET & -3.0937 & $0.0010 * * *$ & -10.5218 & $0.0000 * * *$ \\
\hline TNR & -1.7402 & $0.0409 * *$ & -8.9995 & $0.0000 * * *$ \\
\hline TNG & -1.5400 & $0.0000 * * *$ & -8.9995 & $0.0000 * * *$ \\
\hline MR & -1.7402 & $0.0000 * * *$ & -8.9995 & $0.0000 * * *$ \\
\hline FR & -4.2817 & $0.0000 * * *$ & -7.5193 & $0.0000 * * *$ \\
\hline OR & -1.7402 & $0.0000 * * *$ & -8.9885 & $0.0000 * * *$ \\
\hline CR & -1.7402 & $0.0000 * * *$ & -8.9995 & $0.0000 * * *$ \\
\hline
\end{tabular}

This study adopts the Im-Pesaran-Shin (IPS) test for unit testing, an LLC test extension.

Cointegration test.

We also apply the Pedroni cointegration test (Pedroni, 1999, 2004) since it allows the existence of long-run relationships and cross-sectional interdependence along with different individual effects, such as fixed effects and deterministic trends

Pedroni's cointegration tests:

No. of Panel units: 15

Regressors: 7

No. of obs.: 330

Avg obs. per unit: 22

Data has been time-demeaned. 
Table 4. Pedroni's cointegration tests

\begin{tabular}{rcc}
\hline Test Stats. & Panel & Group \\
\hline V & -2.14 & . \\
Rho & 1.983 & 3.26 \\
T & -9.497 & -12.29 \\
Adf & 2.227 & 4.913 \\
\hline
\end{tabular}

All test statistics are distributed $\mathrm{N}(0,1)$, under a null of no cointegration,

and diverge to negative infinity (save for panel v).

\section{Results}

As reported in the first section of table 5 above, the long-run results indicate that the coefficient of net foreign direct investment (FDI) is 0.29 ; it is positive and statistically significant at $1 \%$. This means that a unit increase in net foreign direct investment (FDI) causes 0.29 increases in GDP growth (Economic growth). The effect of total natural resources (TNR) is also positive and significant at $1 \%$. The coefficient of total natural resources (TNR) with respect to GDP growth is 2.88 , indicating that for every unit increase in total natural resources (TNR), GDP growth increases by 2.88 units. The effect of total natural gas (TNG) is also positive and statistically significant at $1 \%$. It has the highest effect among all the natural resources and even the total natural resources (TNR). This evidence is supported by the findings of (Huang 2020) and (Ben-Salha et al., 2018), who found that FDI and natural resources rent positively affect economic growth in 25 developing countries in Asia and top resource-abundant countries over the period 1970-2013, respectively. We also found that the effect of mineral resources rent (MR), forest resources rent (FR), and oil resources rent (OR) are also statistically significant at $1 \%$ but negatively related to economic growth in West Africa. This finding is also supported by (Erdoğan et al., 2020) and (Pérez \& Claveria, 2020). The second section of Table 5 also presents the short-run coefficients and the error correction term (ECT). The error correction term (ECT) has a negative value of -0.889 , signifying cointegration at a $1 \%$ significance level. This also implies that the short-run estimates converge towards the long-run estimates to achieve equilibrium at the speed of $89 \%$ per annum. We also highlight the pooled mean group (PMG) assumption that the short-run estimates are not the same across countries because they are heterogeneous. However, the selected West African economies may have something familiar to them.

Pooled Mean Group Regression

(Estimate results saved as PMG)

Table 5. Regression results

\begin{tabular}{lc}
\hline & D.GDP \\
\hline Long run coefficients & $0.290^{* * *}$ \\
FDI & $(0.061)$ \\
TNR & $2.880^{* * *}$ \\
& $(0.962)$ \\
TNG & $3.212^{* * *}$ \\
MR & $(0.939)$ \\
& $-2.894 * * *$ \\
FR & $(0.961)$ \\
& $-2.862 * * *$ \\
OR & $(0.965)$ \\
& $-2.735 * * *$ \\
CR & $(1.006)$ \\
Short-run coefficients & 8.564 \\
Ec & $(19.081)$ \\
& $-0.889 * * *$ \\
D.FDI & $(0.079)$ \\
D.TNR & 0.010 \\
D.TNG & $(0.141)$ \\
D.MR & 1078.225 \\
D.FR & $(1081.491)$ \\
D.OR & -1084.196 \\
& $(1084.215)$ \\
& 1080.578 \\
& $(1084.468)$ \\
& 1086.228 \\
& $(1083.943)$ \\
& 1093.133 \\
\end{tabular}




$\begin{array}{lc} & (1090.349) \\ \text { D.CR } & 281.229 \\ \text { Cons } & (282.278) \\ & 2.314^{* * *} \\ \text { Obs. } & (0.486) \\ & 315\end{array}$

Standard errors are in parenthesis

$* * * \mathrm{p}<0.01, * * \mathrm{p}<0.05, * \mathrm{p}<0.1$

The extended version of table 5 is reported below as table 6. It reports both the long-run coefficients of the pooled mean group (PMG) regression and the short-run coefficients of all the 15 countries under observation. The short-run error correction terms are all statistically significant at $1 \%$. We also found that the impact of the independent variables is heterogeneous across countries. For instance, in Ghana, the FDI is not significant, but total natural resources rent is positive and significant at $1 \%$, while forest and oil rent are also negatively significant at $1 \%$. In Benin, FDI is positive and statistically significant at $5 \%$, while total natural resource rent is negative and significant at $1 \%$, but oil rent is positive and significant at $1 \%$.

Table 6. Regression results

\begin{tabular}{|c|c|}
\hline & D.GDP \\
\hline FDI & $\begin{array}{c}0.290 * * * \\
(0.061)\end{array}$ \\
\hline TNR & $\begin{array}{c}2.880 * * * \\
(0.962)\end{array}$ \\
\hline TNG & $\begin{array}{c}3.212 * * * \\
(0.939)\end{array}$ \\
\hline MR & $\begin{array}{c}-2.894 * * * \\
(0.961)\end{array}$ \\
\hline FR & $\begin{array}{c}-2.862 * * * \\
(0.965)\end{array}$ \\
\hline OR & $\begin{array}{c}-2.735 * * * \\
(1.006)\end{array}$ \\
\hline $\mathrm{CR}$ & $\begin{array}{c}8.564 \\
(19.081)\end{array}$ \\
\hline Ghana & \\
\hline Ec & $\begin{array}{c}-0.698 * * * \\
(0.138)\end{array}$ \\
\hline D.FDI & $\begin{array}{c}0.036 \\
(0.250)\end{array}$ \\
\hline D.TNR & $\begin{array}{c}6.347 * * * \\
(0.367)\end{array}$ \\
\hline D.TNG & $\begin{array}{c}0.000 \\
(13.217)\end{array}$ \\
\hline D.MR & $\begin{array}{l}-6.365 \\
(0.000)\end{array}$ \\
\hline D.FR & $\begin{array}{c}-6.658 * * * \\
(0.420)\end{array}$ \\
\hline D.OR & $\begin{array}{c}-5.072 * * * \\
(0.537)\end{array}$ \\
\hline D.CR & $\begin{array}{c}0.000 \\
(0.000)\end{array}$ \\
\hline Cons & $\begin{array}{c}2.639 * * * \\
(0.921)\end{array}$ \\
\hline Benin & \\
\hline $\mathrm{Ec}$ & $\begin{array}{c}-0.616^{* * *} \\
(0.231)\end{array}$ \\
\hline D.FDI & $\begin{array}{l}0.672 * \\
(0.409)\end{array}$ \\
\hline D.TNR & $\begin{array}{c}-27.245^{* * *} * \\
(0.359)\end{array}$ \\
\hline D.TNG & $\begin{array}{c}0.000 \\
(0.000)\end{array}$ \\
\hline D.MR & $\begin{array}{c}0.000 \\
(146.055)\end{array}$ \\
\hline D.FR & 26.677 \\
\hline
\end{tabular}


D.OR

D.CR

Cons

Burkina Faso

Ec

D.FDI

D.TNR

D.TNG

D.MR

D.FR

D.OR

D.CR

Cons

\section{Cape Verde}

Ec

D.FDI

D.TNR

D.TNG

D.MR

D.FR

D.OR

D.CR

Cons

Gambia

Ec

D.FDI

D.TNR

D.TNG

D.MR

D.FR

D.OR

D.CR

Cons

Guinea

Ec

D.FDI
(0.000)

$28.555^{* * * *}$

(6.620)

0.000

(0.000)

$2.421 * *$

(1.028)

$-1.192 * * *$

(0.169)

0.085

(0.368)

$-0.471 * *$

(0.212)

0.000

(0.000)

$0.675^{* *}$

(0.313)

0.000

(0.000)

0.000

(0.000)

0.000

(0.000)

$6.301 * * *$

(1.369)

$-0.457 * *$

(0.178)

0.243

(0.326)

$-5.483$

(9.657)

0.000

(0.000)

0.000

(0.000)

0.000

(0.000)

0.000

(0.000)

0.000

(0.000)

1.604

(1.146)

$-1.335^{* * *}$

(0.226)

$-0.834 *$

(0.486)

$-1.774 * *$

(0.806)

0.000

(0.000)

0.000

(0.000)

0.000

(0.000)

0.000

(0.000)

0.000

(0.000)

2.746**

(1.224)

$-0.756 * * *$

(0.263)

0.057 
D.TNR

(0.114)

$-0.311$

D.TNG

(0.285)

0.000

(0.000)

D.MR

0.216

(0.447)

D.FR

0.000

(0.000)

D.OR

0.000

(0.000)

D.CR

0.000

(0.000)

Cons

$2.481 * *$

(1.212)

Guinea Bissau

Ec

$-0.678 * * *$

(0.216)

D.FDI

1.235

(0.896)

D.TNR

$-1.252^{* * * *}$

(0.357)

0.000

(0.000)

0.000

(0.000)

0.000

(0.000)

0.000

(0.000)

0.000

(0.000)

0.142

(1.743)

Ivory Coast

Ec

$-0.834 * * *$

(0.135)

0.510

(0.409)

D.TNR

$-12.385 * * *$

(3.962)

0.000

(0.000)

$10.376^{*}$

(5.429)

$10.914 * * *$

(3.870)

$12.112 * * *$

(4.145)

0.000

(0.000)

$-0.453$

(0.940)

Mauritania

Ec

$-1.008 * * *$

(0.149)

$-0.119$

(0.119)

0.426

(1.293)

0.000

(0.000)

$-0.427$

(1.283)

0.000

(0.000)

0.267

(1.205) 
D.CR

Cons

Mali

Ec

D.FDI

D.TNR

D.TNG

D.MR

D.FR

D.OR

D.CR

Cons

Niger

Ec

D.FDI

D.TNR

D.TNG

D.MR

D.FR

D.OR

D.CR

Cons

Nigeria

Ec

D.FDI

D.TNR

D.TNG

D.MR

D.FR

D.OR

D.CR

Cons

Togo

Ec

D.FDI

D.TNR
0.000

(0.000)

0.957

(0.980)

$-1.180 * * *$

(0.241)

0.217

(0.365)

$-0.206$

(0.462)

0.000

(0.000)

0.000

(0.000)

$-0.592$

(1.205)

0.000

(0.000)

0.000

(0.000)

$5.068 * * *$

(1.311)

$-1.384 * * *$

(0.195)

$-0.799 * *$

(0.381)

$-1.347 * * *$

(0.425)

0.000

(0.000)

0.000

(3.292)

1.020

(0.000)

0.967

(0.745)

$-14.667$

(17.617)

3.466

(2.591)

$-0.382 * *$

(0.182)

$-0.584$

(1.043)

$-2.267$

(8244035.994)

0.262

(8244035.994)

$-59.048$

(8244035.994)

0.000

(8244035.994)

2.166

(8244035.994)

4233.104

(8244036.438)

$-0.667$

(1.208)

$-0.758 * * *$

(0.210)

$-0.128$

(0.167)

0.265

(0.676) 
D.TNG

D.MR

D.FR

D.OR

D.CR

Cons

Sierra Leone

Ec

D.FDI

D.TNR

D.TNG

D.MR

D.FR

D.OR

D.CR

Cons

Senegal

Ec

D.FDI

D.TNR

D.TNG

D.MR

D.FR

D.OR

D.CR

Cons

Obs.
0.000

$(0.000)$

$-0.369$

(0.772)

0.000

$(0.000)$

0.000

(0.000)

0.000

$(0.000)$

2.078*

(1.238)

$-0.970 * * *$

(0.167)

$-0.106$

(0.246)

0.000

(0.000)

0.000

$(0.000)$

$0.582 * * *$

(0.161)

0.649

(0.517)

0.000

(0.000)

0.000

(0.000)

2.830

(2.030)

$-1.090^{* * *}$

(0.297)

$-0.327$

(0.519)

16219.076

(14566.842)

$-16263.208$

(14556.472)

16263.028

(14556.329)

16261.410

(14556.914)

16357.998

(15015.217)

0.000

$(0.000)$

3.093*

(1.873)

315

Standard errors are in parenthesis

$* * * \mathrm{p}<0.01, * * \mathrm{p}<0.05, * \mathrm{p}<0.1$

\section{Conclusion}

This study focused on evaluating the impact of rent from a natural resource in the form of gas rent, oil rent, coal rent, forest rent, total natural resources rent, fossil fuel energy, and a net inflow of foreign direct investment (FDI) on economic growth for fifteen (15) West African countries. Based on macroeconomic theory, it is expected that the revenues generated from these resources and the net receipts from foreign direct investment FDIs will stimulate economic growth in the respective countries. Accordingly, this study provides evidence of positive and significant impact from net inflows of foreign direct investment (FDI), total natural resources, and total natural gas on economic growth in West Africa in the long run. In sharp contrast, we established that the contribution of mineral resources, forest resources, and oil resources adversely and significantly affected West Africa's economic growth in the long run while coal recorded no significance. These findings grossly contradict the expected relation, but our result is consistent with 
the devastations, pollution, and environmental hazards caused by mining activities in West Africa, mostly due to illegal small scale miners and the gross disregard by multinational Mining Corporation to weak laws.

This environmental degradation phenomenon (water, land, and air pollution) through mining activities has denied most rural folks their sources of livelihood and posed severe health consequences to people, especially in mining areas. The severe other reason is what the literature considers as the "Dutch disease," describing the phenomenon of the mass dependence and concentration of the workforce on natural resources (mostly oil and gold) at the expense of other sectors such as agriculture. The negative relationship between mineral resources, forest resources, and oil resources is also partly due to small state or government interest in the extractive industry in West Africa. The majority of the mining or the extraction of natural resources (gold, oil, gas, etc.) is undertaken by foreign multinationals with little or no state interest but only to pay taxes and royalties. Our findings provide significant impetus to a clarion call for West African countries to diversify their economies from the historical dependence on revenue from natural resources to a more resilient and robust capital market to escape the shackles of the volatile commodities market. We also suggest governments need to increase their interest or ownership in the extraction sector; so their economies can benefit from rising prices or dividends. Financial innovation and financial liberalization of capital markets accompanied by human resources development will also serve as a significant pull factor for FDIs to Africa.

\section{Suggestion for further study:}

This study can further be extended by including human capital and institutional quality indicators into the model to capture their marginal effects on natural resources and economic growth.

\section{References}

Abdulahi, M. E., Shu, Y., \& Khan, M. A. (2019). Resource rents, economic growth, and the role of institutional quality: A panel threshold analysis. Resources Policy, 61, 293-303. https://doi.org/10.1016/j.resourpol.2019.02.011

Abdulnasser, H. J. (last). (2012). Asymmetric causality tests with an application | SpringerLink. https://link.springer.com/article/10.1007/s00181-011-0484-x

Amiri, H., Samadian, F., Yahoo, M., \& Jamali, S. J. (2019). Natural resource abundance, institutional quality, and manufacturing development: Evidence from resource-rich countries. Resources Policy, 62, 550-560. https://doi.org/10.1016/j.resourpol.2018.11.002

Ben-Salha, O., Dachraoui, H., \& Sebri, M. (2018). Natural resource rents and economic growth in the top resource-abundant countries: A PMG estimation. Resources Policy. https://doi.org/10.1016/j.resourpol.2018.07.005

Erdoğan, S., Yıldırım, D. Ç., \& Gedikli, A. (2020). Natural resource abundance, financial development, and economic growth: An investigation on Next-11 countries. Resources Policy, 65, 101559. https://doi.org/10.1016/j.resourpol.2019.101559

Gerelmaa, L., \& Kotani, K. (2013). Further investigation of natural resources and economic growth: Do natural resources depress economic growth? In Working Papers (EMS_2013_07; Working Papers). Research Institute, International University of Japan. https://ideas.repec.org/p/iuj/wpaper/ems_2013_07.html

Hacker, R. S., \& Hatemi, J, A. (2006). Tests for causality between integrated variables using asymptotic and bootstrap distributions: Theory and application. Applied Economics, 38(13), 1489-1500.

Hao, Y., Hu, X., \& Chen, H. (2019). On the relationship between water use and economic growth in China: New evidence from simultaneous equation model analysis. Journal of Cleaner Production, 235, 953-965. https://doi.org/10.1016/j.jclepro.2019.07.024

Hassan, S. T., Xia, E., Huang, J., Khan, N. H., \& Iqbal, K. (2019). Natural resources, globalization, and economic growth: Evidence from Pakistan. Environmental Science and Pollution Research, 26(15), 15527-15534. https://doi.org/10.1007/s11356-019-04890-z

Havranek, T., Horvath, R., \& Zeynalov, A. (2016). Natural Resources and Economic Growth: A Meta-Analysis. World Development, 88, 134-151. https://doi.org/10.1016/j.worlddev.2016.07.016

Havranek, T., Irsova, Z., \& Vlach, T. (2018). Measuring the Income Elasticity of Water Demand: The Importance of Publication and Endogeneity Biases. Land Economics, 94(2), 259-283. https://doi.org/10.3368/le.94.2.259

Henri, P. A. O. (2019). Natural resources curse: A reality in Africa. Resources Policy, 63, 101406. https://doi.org/10.1016/j.resourpol.2019.101406

Henry, A. (2019). Transmission channels of the resource curse in Africa: A time perspective. Economic Modelling, 82, 13-20. https://doi.org/10.1016/j.econmod.2019.05.022

Holden, S. (2013). Avoiding the resource curse the case Norway. Energy Policy, 63, 870-876. 
https://doi.org/10.1016/j.enpol.2013.09.010

Horváth, R., \& Zeynalov, A. (2016). Natural resources, manufacturing and institutions in post-Soviet countries. Resources Policy, 50, 141-148. https://doi.org/10.1016/j.resourpol.2016.09.007

Huang, Y. (2020). The role of forest resources, mineral resources, and oil extraction in economic progress of developing Asian economies. Resources Policy, 13.

Madreimov, T., \& Li, L. (2019). Natural-resource dependence and life expectancy: A nonlinear relationship. Sustainable Development, 27(4), 681-691. https://doi.org/10.1002/sd.1932

Mueller, T. (2019). Natural Resource Dependence and Rural American Economic Prosperity from 2000 to 2015. SocArXiv. https://doi.org/10.31235/osf.io/5pcwm

Olayungbo, D. O. (2019). Effects of oil export revenue on economic growth in Nigeria: A time varying analysis of resource curse. Resources Policy, 64, 101469. https://doi.org/10.1016/j.resourpol.2019.101469

Pérez, C., \& Claveria, O. (2020). Natural resources and human development: Evidence from mineral-dependent African countries using exploratory graphical analysis. Resources Policy, 65, 101535. https://doi.org/10.1016/j.resourpol.2019.101535

Rantao, K.-O. (2019). The role of MNCs as a channel of the resource 'curse': Insights from gas-rich Mozambique [Mini Dissertation, University of Pretoria]. https://repository.up.ac.za/handle/2263/74837

Redmond, T., \& Nasir, M. A. (2020). Role of natural resource abundance, international trade and financial development in the economic development of selected countries. Resources Policy, 66, 101591. https://doi.org/10.1016/j.resourpol.2020.101591

Soejoto, Ady, Hendry Cahyono, \& Solikhah, matush. (2017). How does natural resource dependence affect public education spending? | SpringerLink. https://link.springer.com/article/10.1007/s11356-018-3853-6

Tuna, G., \& Tuna, V. E. (2019). The asymmetric causal relationship between renewable and NON-RENEWABLE energy consumption and economic growth in the ASEAN-5 countries. Resources Policy, 62, 114-124. https://doi.org/10.1016/j.resourpol.2019.03.010

Wegenast, T., Khanna, A., \& Schneider, G. (2018). The Micro-Foundations of the Resource Curse: Oil Ownership and Local Economic Well-Being in Sub-Saharan Africa [WORKINGPAPER]. https://kops.uni-konstanz.de/handle/123456789/41571

Zallé, O. (2019). Natural resources and economic growth in Africa: The role of institutional quality and human capital. Resources Policy, 62, 616-624. https://doi.org/10.1016/j.resourpol.2018.11.009

\section{Copyrights}

Copyright for this article is retained by the author(s), with first publication rights granted to the journal.

This is an open-access article distributed under the terms and conditions of the Creative Commons Attribution license which permits unrestricted use, distribution, and reproduction in any medium, provided the original work is properly cited. 